\title{
The Influence of Obesity on Blood Pressure in Early Adulthood and Middle Adulthood Males
}

\author{
Muhammad O.A Eusman*, Hana Ratnawati**, Mariska Elisabeth*** \\ *Faculty of Medicine Maranatha Christian University \\ **Department of Histology Faculty of Medicine, Maranatha Christian University \\ ***Department of Anatomical Pathology \\ Faculty of Medicine Maranatha Christian University \\ Jl. Prof. drg. Suria Sumantri MPH No.65 Bandung 40164 Jawa Barat Indonesia \\ Email : hana.ratnawati@gmail.com
}

\begin{abstract}
Hypertension is commonly found in obesity patients. Age affects the occurrence of hypertension. The aim of this study is to determine the effect of obesity on blood pressure levels in early adulthood males ( $<35$ years) and middle adulthood males $(\geq 35$ years). This is an observational analytic study using data from medical check-up records of male adult office workers in Bandung. The data was analyzed with Mann-Whitney test $(\alpha=0.05)$ and Chi-Square to find the odds ratio $(O R)$. The results showed that out of 110 data in medical records, there were $79(71.82 \%)$ obese and 31 (28.18\%) non-obese. In early adulthood males (<35 years) there is no significant difference between non-obese with obese in systolic blood pressure $(p=0.779)$ and diastolic blood pressure $(p=0.779)$. In middle adulthood males $(\geq 35$ years) there was a highly significant difference between non-obese with obese on systolic blood pressure $(p=0.001)$ and diastolic blood pressure $(p=0.003)$. There was a significant relationship between obesity and hypertension $(p=0.048)$ with $O R=3.73$. In conclusion, in early adulthood males ( $<35$ years) obese does not have an effect on the development of hypertension, while in middle adulthood males, obesity increases the risk of developing hypertension by 3.73 times.
\end{abstract}

Keywords: obesity, blood pressure, early adulthood males, middle adulthood males 


\title{
Pengaruh Obesitas terhadap Tekanan Darah pada Pria Dewasa Muda dan Dewasa Madya
}

\author{
Muhammad O.A Eusman*, Hana Ratnawati**, Mariska Elisabeth ${ }^{* * *}$ \\ * Fakultas Kedokteran Universitas Kristen Maranatha \\ **Bagian Histologi Fakultas Kedokteran Universitas Kristen Maranatha \\ ***Bagian Patologi Anatomi Fakultas Kedokteran Universitas Kristen Maranatha \\ Jl. Prof.Drg.Surya Sumantri, MPH No 65 Bandung 40164 Indonesia \\ Email: hana.ratnawati@gmail.com
}

\begin{abstract}
Abstrak
Hipertensi merupakan komorbiditas tersering pada penderita obesitas. Usia berpengaruh terhadap terjadinya hipertensi. Tujuan penelitian ini yaitu untuk mengetahui pengaruh obesitas terhadap tekanan darah pada pria dewasa muda $(<35$ tahun) dan pria dewasa madya $(\geq 35$ tahun). Penelitian ini bersifat observational analitik dengan data penelitian adalah data medical check-up karyawan pria dewasa suatu perkantoran di Bandung. Data ditabulasi dan dianalisis dengan Mann-Whitney test dengan $\alpha=0,05$ serta uji Chi-Square untuk mengetahui Odds Ratio (OR). Hasil penelitian menunjukkan bahwa dari 110 data di rekam medis, terdapat $79(71,82 \%)$ dengan obesitas dan $31(28,18 \%)$ tidak obesitas. Pada kelompok pria dewasa muda $(<35$ tahun) tidak terdapat perbedaan bermakna tekanan darah sistolik $(\mathrm{p}=0,779)$ dan diastolik $(\mathrm{p}=0,779)$ antara kelompok obesitas dan tidak obesitas. Pada kelompok pria dewasa madya ( $\geq 35$ tahun) terdapat perbedaan sangat bermakna tekanan darah sistolik $(p=0,001)$ dan diastolik $(p=0,003)$ antara kelompok obesitas dan tidak obesitas. Pada pria dewasa madya, didapatkan hubungan bermakna antara obesitas dengan hipertensi $(p=0,048)$ dengan $O R=3,73$. Simpulan penelitian ini adalah pada pria dewasa muda $(<35$ tahun) obesitas tidak berpengaruh terhadap terjadinya hipertensi, sedangkan pada pria dewasa madya ( $\geq 35$ tahun) dengan obesitas, peluang terkena hipertensi meningkat 3,73 kali dibandingkan yang tidak obesitas.
\end{abstract}

Kata kunci: obesitas, tekanan darah, pria dewasa muda, pria dewasa madya 


\section{Pendahuluan}

Obesitas merupakan salah satu masalah epidemi dunia dengan lebih dari 1,9 miliar orang mempunyai berat badan berlebih dan lebih dari 650 juta tergolong ke dalam obesitas. ${ }^{1}$ Menurut Riset Kesehatan Dasar (2013), prevalensi obesitas pada pria dewasa di Indonesia sebesar $15,4 \%$. Penyumbang terbesar berasal dari Sulawesi Utara sebesar 24\% dan terendah berasal dari Nusa Tenggara Timur sebesar 6,2\%. Jawa Barat termasuk dalam enam belas provinsi dengan prevalensi obesitas diatas rata-rata prevalensi nasional. ${ }^{2}$

Menurut World Health Organization (WHO), obesitas adalah akumulasi lemak yang abnormal atau berlebihan yang bisa menyebabkan berbagai penyakit. ${ }^{1}$ Penyebab utama obesitas adalah ketidakseimbangan antara kalori yang masuk dan keluar, umumnya akibat konsumsi makanan yang tinggi lemak jenuh ataupun kurangnya aktivitas yang disebabkan sedentary life style. Obesitas merupakan faktor risiko bagi penyakit kardiovaskular (terutama penyakit jantung dan stroke), diabetes mellitus, gangguan muskuloskeletal, dan penyakit keganasan. ${ }^{1}$ Penelitian dari Framingham Heart Study menyatakan bahwa insidensi obesitas meningkat pada usia di atas 35 tahun dan risiko kejadian hipertensi meningkat 2,6 kali pada subjek pria obesitas dibandingkan subjek dengan berat badan normal. ${ }^{3}$

Hipertensi didefinisikan sebagai tekanan darah sistolik $\geq 140 \mathrm{mmHg}$ dan atau tekanan darah diastolik $\geq 90 \mathrm{mmHg}$, atau sedang menggunakan obat-obatan antihipertensi. ${ }^{4}$ Prevalensi hipertensi di Jawa Barat sebesar 29,4\%, lebih tinggi dibandingkan prevalensi hipertensi secara nasional yaitu 25,8\%. ${ }^{2}$ Hipertensi yang tidak mendapat penanganan yang baik dapat menimbulkan berbagai komplikasi yang berbahaya seperti stroke, gagal jantung, gagal ginjal dan gangguan penglihatan pada pria maupun wanita. Stroke (51\%) dan penyakit jantung koroner (45\%) merupakan penyebab kematian tertinggi. ${ }^{5}$

Obesitas dapat menginduksi hipertensi melalui berbagai mekanisme, seperti peningkatan sistem simpatis, aktivasi sistem renin-angiotensin aldosterone (Sistem RAA), gangguan pompa natrium, dan lesi aterosklerosis. ${ }^{6}$ Pada keadaan obesitas, dapat mengaktivasi sistem RAA tersebut, mengkompresi ginjal dan meningkatkan aktivasi sistem saraf simpatis. ${ }^{7}$ Sistem RAA ini awalnya merupakan suatu mekanisme perlindungan jika terjadi penurunan aliran darah menuju ginjal, namun jika terjadi gangguan pada keseimbangan sistem ini akan menyebabkan vasokontriksi yang semakin parah. ${ }^{8}$

Distribusi abnormal asam lemak bebas pada penderita obesitas dengan hipertensi dapat menyebabkan peningkatan sensitivitas $\alpha$-adrenergik pada endotel dan akibatnya terjadi peningkatan respon simpatis. Asam lemak bebas menghambat pompa natrium dan pompa kalium dan ATPase sehingga meningkatkan kontraksi otot polos pada endotel dan resistensi 


\section{Research Article}

perifer. Berbagai mekanisme ini menyebabkan hipertensi dan dapat menyebabkan suatu jejas pada endotel. ${ }^{9}$ Jejas vaskular ini menyebabkan disfungsi endotel dan otot polos pembuluh darah. Penyembuhan pembuluh darah melibatkan migrasi sel otot polos ke tunika intima, disini sel-sel tersebut berproliferasi dan menyintesis matriks ekstraselular dan fibroblast sehingga membentuk suatu neointima yang secara mekanik mudah ruptur. ${ }^{6}$

Menurut penelitian didapatkan bukti-bukti bahwa sel otot polos pada neointima tidak memiliki kemampuan untuk berkontraksi seperti sel otot polos yang terdapat pada tunika media, namun memiliki kemampuan membelah dan mensintesis yang jauh lebih besar. Jika terjadi kerusakan sifatnya kronis dan persisten, penebalan dapat berlanjut dan mengakibatkan sumbatan yang lebih hebat sehingga terjadi hipertensi yang lebih berat. ${ }^{6}$ Jika lumen pembuluh darah mengalami suatu sumbatan sehingga diameternya menjadi 1/2 dari ukuran lumen awal, akan menyebabkan penurunan aliran hingga 1/16 kalinya, menyebabkan penurunan aliran terutama ke ginjal dan terjadilah aktivasi sistem RAA sehingga menyebabkan terjadinya hipertensi dengan berbagai manifestasi klinis. ${ }^{6,9,10}$

Usia sangat berpengaruh terhadap peningkatan tekanan darah dimana seiring dengan bertambahnya usia terjadi peningkatan risiko obesitas dan hipertensi, itu sebabnya dalam meneliti pengaruh obesitas perlu diperhitungkan faktor usia. Ada beberapa pembagian kelompok usia, antara lain ada yang membaginya menjadi 2 kelompok yaitu dewasa muda (1835 tahun) dan dewasa madya (36-50 tahun). ${ }^{11}$

Pada penelitian ini akan dibagi menjadi 2 kelompok usia yaitu dewasa muda di bawah 35 tahun dan dewasa madya di atas sama dengan 35 tahun. Tujuan penelitian ini adalah untuk mengetahui bagaimana pengaruh obesitas terhadap tekanan darah pada pria dewasa berdasarkan kelompok umur di bawah 35 tahun dan di atas sama dengan 35 tahun. Penelitian ini diharapkan dapat memberi manfaat bagi masyarakat mengenai pentingnya menjaga berat badan ideal, terutama bagi golongan dewasa madya, karena obesitas memiliki risiko tinggi terkena berbagai penyakit, khususnya hipertensi.

\section{Metode}

Penelitian ini bersifat analitik observational, dengan teknik pengambilan sampel data secara potong lintang terhadap data medical check-up seluruh karyawan pria suatu perkantoran di kota Bandung, yang telah dilakukan cek kesehatan terhadap karyawannya pada periode Februari-Maret 2017. Lokasi penelitian di kantor "X" di kota Bandung dan Fakultas Kedokteran Universitas Kristen Maranatha. Waktu penelitian bulan Januari sampai dengan Mei 2018. 


\section{Research Article}

Populasi pada penelitian ini adalah seluruh data (whole sample) medical check-up dengan jumlah 110 sampel yang dibagi menjadi 2 kelompok yaitu usia dewasa muda $(<35$ tahun) dan dewasa madya ( $\geq 35$ tahun) yang memenuhi kriteria inklusi dan eksklusi. Kriteria inklusi ialah pria dewasa usia 21-65 tahun, IMT (Indeks Massa Tubuh) obesitas $\geq 25 \mathrm{~kg} / \mathrm{m}^{2}$, dan IMT tidak obesitas $<25 \mathrm{~kg} / \mathrm{m}^{2}{ }^{1}$ Kriteria eksklusi ialah pasien dengan data medical check-up tidak lengkap.

Analisis data menggunakan uji Mann-Whitney dengan $\alpha=0,05$, dengan tujuan untuk melihat adanya perbedaan tekanan darah sistol dan diastol pada pria dewasa muda dan pria dewasa madya. Untuk mengetahui seberapa besar pengaruh obesitas terhadap peningkatan tekananan darah digunakan analisis statistik Chi-Square dengan $\alpha=0,05$.

\section{Hasil}

Penelitian ini telah mendapat persetujuan dari Komisi Etik Penelitian Fakultas Kedokteran Universitas Kristen Maranatha dan Rumah Sakit Immanuel Bandung dengan nomor 168/KEP/III/2018.

\section{Karakteristik Subjek Penelitian Berdasarkan Usia}

Data rekam medis yang memenuhi kriteria inklusi berjumlah 110 data dan didapatkan IMT obesitas 79 orang $(71,82 \%)$ dan IMT tidak obesitas (non-obes) 31 orang $(28,18 \%)$. Usia subjek penelitian yang termuda adalah 22 tahun dan yang tertua adalah 64 tahun. Penyebaran data berdasarkan usia dapat dilihat pada gambar 1.

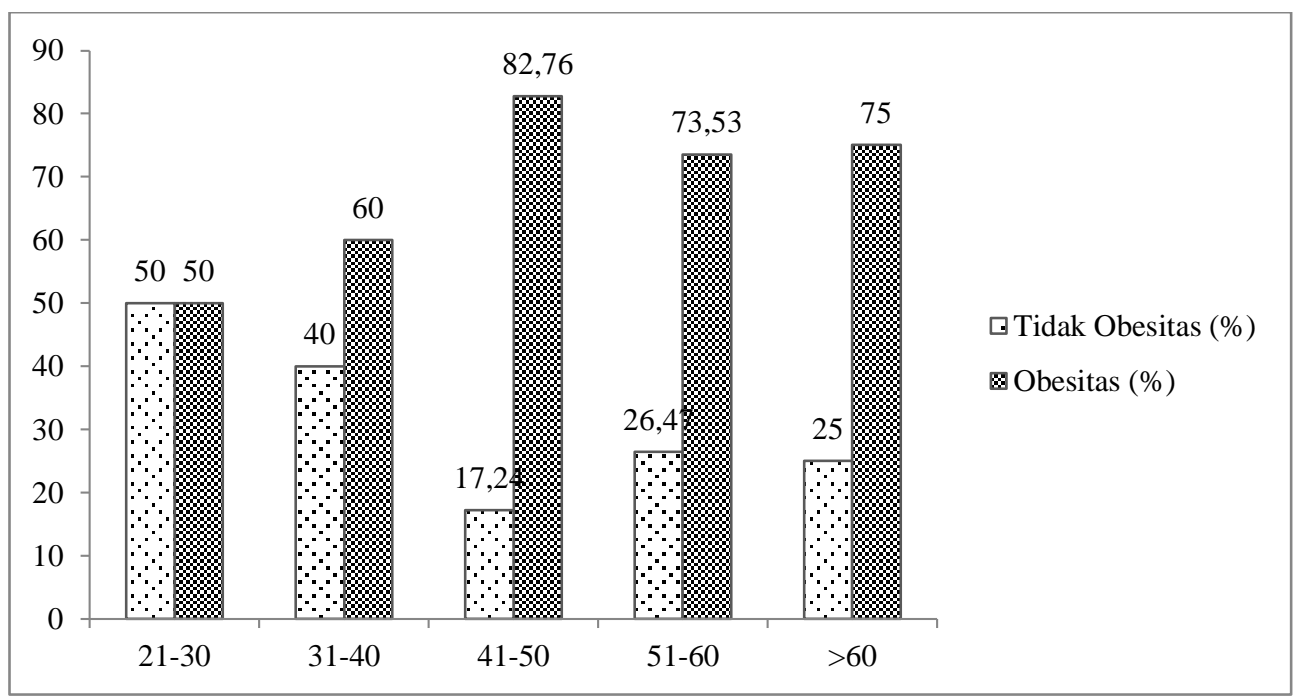

Gambar 1 Perbandingan Persentase Obesitas dan Tidak Obesitas Berdasarkan Kelompok Umur 
Pada gambar 1 dapat dilihat bahwa persentase obesitas semakin meningkat dengan meningkatnya usia. Pada kelompok usia 21-30 tahun, perbandingan tidak obesitas dengan obesitas 1 : 1, namun pada kelompok usia 41-50 tahun, perbandingannya menjadi $1: 4,8$. Namun pada usia di atas 60 tahun, perbandingannya menurun lagi menjadi $1: 3$

\section{Karakteristik Subjek Penelitian Berdasarkan IMT dan Tekanan Darah}

Karakteristik subjek penelitian berdasarkan IMT dan tekanan darah dapat dilihat pada tabel 1 berikut ini:

Tabel 1 Subjek Penelitian berdasarkan IMT dan Tekanan Darah

\begin{tabular}{cccccc}
\hline \multirow{2}{*}{$\begin{array}{c}\text { Usia } \\
\text { (Tahun) }\end{array}$} & \multirow{2}{*}{ Jumlah } & \multicolumn{2}{c}{ IMT } & \multicolumn{2}{c}{ Tekanan Darah } \\
\cline { 3 - 6 } & & Tidak Obesitas $(\%)$ & Obesitas $(\%)$ & Normal $(\%)$ & Hipertensi $(\%)$ \\
\hline$<35$ & 29 & $13(44,83)$ & $16(55,17)$ & $27(93,10)$ & $2(6,90)$ \\
$\geq 35$ & 81 & $18(22,22)$ & $63(77,78)$ & $55(67,90)$ & $26(32,10)$ \\
\hline
\end{tabular}

Dari tabel 2 dapat dilihat bahwa pada kelompok usia $<35$ tahun IMT tidak obesitas yaitu sebanyak 44,83\% dan obesitas sebesar $55,17 \%$, namun tekanan darah di atas normal hanya $6,90 \%$. Pada kelompok usia $\geq 35$ tahun terjadi peningkatan subjek obesitas menjadi $77,78 \%$ dan tekanan darah di atas normal menjadi $22,22 \%$.

\section{Perbedaan tekanan darah pada IMT Obesitas dan Tidak Obesitas}

Untuk melihat apakah terdapat perbedaan bermakna antara tekanan darah sistolik maupun diastolik pada IMT obesitas dan IMT tidak obesitas berdasarkan kelompok umur <35 tahun dan $\geq 35$ tahun, maka dilakukan analisis secara statistik dengan menggunakan MannWhitney test. Hasil analisis data ditampilkan pada tabel 2 dan tabel 3.

\section{Tabel 2 Perbedaan Tekanan Darah Sistolik dan Diastolik Pada Pria Dewasa Muda dengan Obesitas dan Tidak Obesitas.}

\begin{tabular}{cccc}
\hline Tekanan Darah & N & Rerata Tekanan Darah & Mann-Whitney Test \\
\hline Sistolik & 29 & $109,66 \pm 11,49$ & 0,779 \\
Diastolik & 29 & $77,24 \pm 6,49$ & 0,779 \\
\hline
\end{tabular}

Dari tabel 2 dapat dilihat bahwa hasil Mann-Whitney test terhadap tekanan darah sistolik maupun tekanan darah diastolik pada kelompok usia $<35$ tahun dengan obesitas maupun tidak obesitas menunjukkan hasil yang tidak bermakna ( $>>0,05$ ). Hal ini menunjukkan bahwa pada pria dewasa muda ( $<35$ tahun) dengan atau tanpa obesitas, tidak terdapat perbedaan tekanan darah sistolik maupun diastolik. 
Tabel 3 Perbedaan Tekanan Darah Sistolik dan Diastolik pada Pria Dewasa Madya dengan Obesitas dan Tidak Obesitas.

\begin{tabular}{cccc}
\hline Tekanan Darah & N & Rerata Tekanan Darah & Mann-Whitney \\
\hline Sistolik & 81 & $120,99 \pm 16,53$ & 0,001 \\
Diastolik & 81 & $79,75 \pm 8,21$ & 0,003 \\
\hline
\end{tabular}

Dari tabel 3 dapat dilihat bahwa hasil hasil uji Mann-Whitney tekanan darah sistolik maupun tekanan darah diastolik pada kelompok usia $\geq 35$ tahun, dengan obesitas berbeda sangat bermakna dengan kelompok tidak obesitas $(\mathrm{p}<0.01)$.

\section{Pengaruh Obesitas terhadap Tekanan Darah pada Pria Dewasa Madya}

Untuk mengetahui seberapa besar pengaruh IMT obesitas terhadap peningkatan tekanan darah pada pria dewasa madya, maka dilakukan uji Chi-Square, hasilnya dapat dilihat pada tabel 4.

\section{Tabel 4 Pengaruh Obesitas terhadap Peningkatan Tekanan Darah pada Pria Dewasa Madya}

\begin{tabular}{|c|c|c|c|c|c|c|c|}
\hline \multirow{3}{*}{ IMT } & \multicolumn{4}{|c|}{ Tekanan Darah } & \multirow{3}{*}{$\begin{array}{c}\text { Chi- } \\
\text { Squ } \\
\text { are }\end{array}$} & \multirow{3}{*}{ OR } & \multirow{3}{*}{$95 \% \mathrm{CI}$} \\
\hline & \multicolumn{2}{|c|}{ Normal } & \multicolumn{2}{|c|}{ Hipertensi } & & & \\
\hline & $\mathrm{N}$ & $\%$ & $\mathrm{~N}$ & $\%$ & & & \\
\hline Normal & 18 & 22,22 & 3 & 3,70 & \multirow{2}{*}{0,048} & \multirow{2}{*}{3,73} & \multirow{2}{*}{$0,99-14,08$} \\
\hline Obesitas & 37 & 45,68 & 23 & 28,40 & & & \\
\hline
\end{tabular}

Dari uji Chi-square selanjutnya dihitung nilai OR untuk mengetahui seberapa besar pengaruh obesitas terhadap terjadinya hipertensi. Nilai OR didapatkan 3,73 artinya pada pria dewasa madya ( $\geq 35$ tahun) dengan IMT obesitas berpeluang 3,73 kali untuk menderita hipertensi dibandingkan dengan IMT tidak obesitas. Nilai interval rata-rata 95\% Confident Interval (CI) 0,99-14,08 artinya pada populasi pria dewasa (diluar subjek penelitian) yang mempunyai risiko obesitas, nilai OR nya berada diantara 0,99-14,08.

\section{Diskusi}

Dari hasil penelitian didapatkan bahwa dengan semakin meningkatnya usia maka persentase obesitas juga semakin meningkat. Persentase tertinggi obesitas didapatkan pada rentang usia 41-50 tahun yaitu sebesar 82,74\%. Bila dibedakan berdasarkan kelompok umur $<35$ tahun (dewasa muda) dan $\geq 35$ tahun (dewasa madya), maka perbandingan antara yang tidak obesitas dengan yang obesitas pada kelompok umur $<35$ tahun adalah $1: 1,2$, sedangkan pada kelompok umur $\geq 35$ tahun perbandingannya meningkat menjadi $1: 3,5$. Demikian juga untuk 


\section{Research Article}

tekanan darah, semakin lanjut usia maka persentase penderita hipertensi juga semakin meningkat. Pada kelompok umur $<35$ tahun persentase penderita hipertensi adalah 6,90\%, sedangkan pada kelompok umur $\geq 35$ tahun persentasenya meningkat menjadi $32,10 \%$.

Tingginya persentase penderita obesitas pada penelitian ini dapat disebabkan para karyawan kantor memiliki jam kerja yang tinggi dan mayoritas aktivitas di depan komputer, dengan kata lain duduk sepanjang hari, sehingga kurang melakukan aktivitas fisik. Disamping itu, para karyawan juga lebih sering mengonsumsi makanan cepat saji dari rumah makan di sekitar kantor. Hal tersebut meningkatkan risiko terkena obesitas. Bila kebiasaan gaya hidup tersebut berlangsung bertahun-tahun maka risiko terkena obesitas semakin tinggi, sehingga dari hasil penelitian didapatkan saat usia di atas 40 tahun persentase obesitas paling tinggi.

Dari hasil penelitian juga didapatkan bahwa pada kelompok usia $<35$ tahun, meskipun persentase obesitas sebesar $55,17 \%$, tetapi yang mempunyai tekanan darah di atas normal hanya $6,90 \%$. Hal ini berbeda dengan kelompok $\geq 35$ tahun dimana penderita obesitas $77,78 \%$ dan yang menderita hipertensi sebanyak $32,10 \%$. Pada kelompok usia $<35$ tahun tidak terdapat perbedaan rerata tekanan darah sistolik maupun diastolik baik pada IMT obesitas maupun tidak obesitas. Penelitian Yulyius et al. (2013) mendapatkan bahwa dari 100 subjek penelitian siswasiswi SMP dan SMA, sebanyak 21\% mempunyai IMT obesitas, namun tidak terdapat subjek penelitian yang hipertensi. ${ }^{12}$ Hal ini mengindikasikan bahwa pada usia muda, obesitas tidak mempengaruhi peningkatan tekanan darah. Sebaliknya pada kelompok usia $\geq 35$ tahun, terdapat perbedaan yang bermakna $(\mathrm{p}<0.05)$ pada tekanan darah sistolik maupun diastolik antara IMT obesitas dengan tidak obesitas dan didapatkan bahwa IMT obesitas berpeluang 3,73 kali untuk terkena hipertensi dibandingkan dengan IMT tidak obesitas.

Peningkatan risiko penyakit kardiovaskular dimulai dari usia 40 tahun ke atas. ${ }^{13,8}$ Menurut Framingham Heart Study, usia paling banyak menderita obesitas dan hipertensi adalah pada usia di atas 35 tahun, dan juga dikatakan bahwa risiko kejadian hipertensi meningkat 2,6 kali pada subjek laki-laki obesitas. ${ }^{3}$ Penelitian yang dilakukan terhadap karyawan suatu kantor di Bandung, didapatkan bahwa hipertensi pada kelompok usia 41-50 tahun sebesar 50,4\% atau 5 kali lebih tinggi dibandingkan kelompok usia 20-30 tahun dan pada subjek penelitian dengan obesitas akan terjadi peningkatan risiko sebesar 1,681 kali untuk menderita hipertens setelah dikontrol variabel usia, riwayat hipertensi keluarga, dan aktivitas fisik. ${ }^{14}$

Data dari Riskesdas menunjukkan hal yang sama, yaitu prevalensi hipertensi dan obesitas lebih sering terjadi pada usia antara 35-65 tahun. ${ }^{2}$ Penelitian lainnya di Jawa Timur tahun 2015-2016 juga mendapatkan hal yang sama. Apabila terdapat peningkatan kasus obesitas maka kasus hipertensi juga akan mengalami peningkatan dan sebaliknya, jadi terdapat korelasi 


\section{Research Article}

antara obesitas dengan hipertensi. ${ }^{15,16}$ Penelitian pada etnik Minangkabau, hasilnya menunjukkan terdapat hubungan yang bermakna antara kejadian obesitas dengan hipertensi di Kota Padang. ${ }^{17}$

Obesitas dapat memicu terjadinya hipertensi. Hal ini antara lain disebabkan oleh hormon leptin yang dihasilkan oleh jaringan adiposa. Leptin dapat menginduksi saraf simpatis melalui hipotalamus untuk meningkatkan termogenesis. Hal ini dapat menyebabkan peningkatan tekanan darah melalui reseptor adrenergik. ${ }^{10}$ Selain itu pada obesitas terdapat aktivasi sistem RAA yang diduga berperan karena jaringan adiposa menyintesis angiotensinogen dan memengaruhi kadar aldosteron. Aldosteron akan menyebabkan terjadinya peningkatan retensi natrium, sehingga menyebabkan peningkatan tekanan darah. ${ }^{17}$ Pada penderita obesitas juga terjadi perubahan endotel yaitu penebalan tunika intima, tunika media dinding pembuluh darah, dan menurunnya responsivitas terhadap nitric oxide dan endothelin-1 yang akan menyebabkan terjadinya peningkatan resistensi perifer pembuluh darah sehingga diperlukan tekanan lebih besar untuk menyuplai darah ke seluruh tubuh. ${ }^{10}$ Usia berperan terhadap terjadinya obesitas dan peningkatan tekanan darah, karena semakin lanjut usia akan meningkatkan risiko gangguan metabolisme dan homeostatik sehingga meningkatkan risiko obesitas, diabetes, dan penyakit kardiovaskular. ${ }^{15}$

Penambahan berat badan berlebih, terutama jika disertai peningkatan adipositas viseral, berperan sebagai faktor risiko hipertensi sebesar $65-75 \%$. Hal ini menyebabkan terjadi peningkatan reabsorpsi natrium di tubulus ginjal, juga kompresi ginjal oleh lemak dan aktivasi sistem renin-angiotensin-aldosteron, serta peningkatan aktivitas sistem saraf simpatik. ${ }^{18}$ Keterbatasan penelitian ini adalah, tidak didapatkan data faktor-faktor lain yang berpengaruh terhadap obesitas dan hipertensi, seperti faktor genetik, penyakit lain dan konsumsi obat-obatan yang bisa mempengaruhi tekanan darah dan indeks massa tubuh..

\section{Simpulan}

Pada pria dewasa muda $(<35$ tahun), obesitas tidak berpengaruh terhadap terjadinya hipertensi, sedangkan pada pria dewasa madya ( $\geq 35$ tahun) dengan obesitas, berpeluang terkena hipertensi 3,73 kali dibandingkan yang tidak obesitas.

\section{Daftar Pustaka}

1. World Health Organisation. Obesity and overweight [Internet]. World Health Organisation Media Centre Fact Sheet No. 311. 2012. [Cited:2 April 2018]. Available from:https://www.who.int/en/news-room/factsheets/detail/obesity-and-overweight

2. Kementrian Kesehatan. Riset Dasar Kesehatan 2013. Diunduh tanggal 9 Februari 2018. Available from: URL http://www.depkes.go.id/resources/download/general/Hasil\%20Riskesdas\%202013

3. Wilson PWF, D'Agostino RB, Sullivan L, Parise H, Kannel WB. Overweight and obesity as determinants of 


\section{Research Article}

cardiovascular risk: the Framingham experience. Arch Intern Med. 2002;162(16):1867-72.

4. Chobanian AV, Bakris GL, Black HR, Cushman WC, Green LA, Izzo JL, et al. Seventh report of the Joint National Committee on Prevention, Detection, Evaluation, and Treatment of High Blood Pressure. Hypertension. 2003;42(6):1206-52.

5. AHA. Health Threat From High Blood Press [Internet]. [Cited: 7 Februari 2018]. Available from: http://www.heart.org/HEARTORG/Conditions/HighBloodPressure/LearnHowHBPHarmsYourHealth/HealthThreats-From-High-Blood-Pressure_UCM_002051_Article.jsp

6. Kumar. Robbins Basic Pathology, 8th ed. Elsevier. 2007. 446 p.

7. Hall JE, Do Carmo JM, Da Silva AA, Wang Z, Hall ME. Obesity-Induced Hypertension: Interaction of Neurohumoral and Renal Mechanisms. Circ Res. 2015;116(6):991-1006.

8. Sherwood L. Human Physiology: From Cells to System [Internet]. Vol. 7th, Human Physiology. 2010. 376-378 p. Available from: http://books.google.com/books?id=gOmpysGBC90C\&pgis=1

9. Kotsis V, Stabouli S, Papakatsika S, Rizos Z, Parati G. Mechanisms of obesity-induced hypertension. Hypertens Res. 2010;33(5):386-93.

10. Guyton AC, Hall JE. Textbook of Medical Physiology. 8th Ed. Textbook of Medical Physiology. 2006. 164-168 p.

11. NM P. A comparison of young, middle-aged, and older adult treatment-seeking pathological gamblers. pubmed.gov. 2002.

12. Yulyius, Bolang ASL, Kawengian SES. Hubungan Antara Status Gizi Dengan Tekanan Darah Mahasiswa Program Studi Pendidikan Dokter Angkatan 2013 Fakultas Kedokteran Universitas Sam Ratulangi. J eBiomedik. 2013;000(1):7-17. Weisell RC. Body mass index as an indicator of obesity. Asia Pacific J Clin Nutr .2002;11 Suppl:S683.

13. Barzilai N, Huffman DM, Muzumdar RH, Bartke A. The critical role of metabolic pathways in aging. Diabetes. 2012;61(6):1315-22

14. Rohkuswara TD, Syahrizal S. Hubungan Obesitas dengan Kejadian Hipertensi Derajat 1 di Pos Pembinaan Terpadu Penyakit Tidak Menular (Posbindu PTM) Kantor Kesehatan Pelabuhan Bandung Tahun 2016. Jurnal Epidemiologi Kesehatan Indonesia. 2017;1(2):13-18.

15. Barba C, Cavalli-Sforza T, Cutter J, Darnton-Hill I, Deurenberg P, Deurenberg-Yap M, et al. Appropriate bodymass index for Asian populations and its implications for policy and intervention strategies. Lancet. 2004;363(9403):160.

16. Emira TR, Yuly Y. Hubungan Kasus Obesitas dengan Hipertensi di Provinsi Jawa Timur 2015-2016. Jurnal Berkala Epidemiologi. 2018;6(1): 35-42

17. Sulastri D, Ramadhani R, Gizi B, Kedokteran F, Andalas U. Hubungan obesitas dengan kejadian hipertensi pada masyarakat etnik minangkabau di kota padang. Maj Kedokt Andalas. 2012;36(2):188-99.

18. Hall JE, do Carmo JM, da Silva AA, Wang Z, Hall ME. Obesity-Induced Hypertension Interaction of Neurohumoral and Renal Mechanisms. Circ Res. 2015;116(6):991-1006. 